University of Nebraska - Lincoln

DigitalCommons@University of Nebraska - Lincoln

Agronomy \& Horticulture -- Faculty Publications

Agronomy and Horticulture Department

1986

\title{
Evaluation of Agronomic and Energy Traits of Wray Sweet Sorghum and the N39 x Wray Hybrid
}

\author{
Max D. Clegg \\ University of Nebraska-Lincoln, mclegg1@unl.edu
}

H. J. Gorz

University of Nebraska-Lincoln

Jerry W. Maranville

University of Nebraska-Lincoln

Francis A. Haskins

University of Nebraska-Lincoln, fhaskins@neb.rr.com

Follow this and additional works at: https://digitalcommons.unl.edu/agronomyfacpub

Part of the Plant Sciences Commons

Clegg, Max D.; Gorz, H. J.; Maranville, Jerry W.; and Haskins, Francis A., "Evaluation of Agronomic and Energy Traits of Wray Sweet Sorghum and the N39 x Wray Hybrid" (1986). Agronomy \& Horticulture -Faculty Publications. 168.

https://digitalcommons.unl.edu/agronomyfacpub/168

This Article is brought to you for free and open access by the Agronomy and Horticulture Department at DigitalCommons@University of Nebraska - Lincoln. It has been accepted for inclusion in Agronomy \& Horticulture -Faculty Publications by an authorized administrator of DigitalCommons@University of Nebraska - Lincoln. 


\title{
EVALUATION OF AGRONOMIC AND ENERGY TRAITS OF WRAY SWEET SORGHUM AND THE N39 $\times$ WRAY HYBRID
}

\author{
M.D. CLEGG ${ }^{1}$, H.J. GORZ ${ }^{1,2}$, J.W. MARANVILLE ${ }^{1}$ and F.A. HASKINS ${ }^{1}$ \\ ${ }^{1}$ Department of Agronomy and ${ }^{2}$ USDA Agricultural Research Service, University of \\ Nebraska, Lincoln, NE 68583 (U.S.A.)
}

(Accepted 21 August 1985)

\begin{abstract}
Clegg, M.D., Gorz, H.J., Maranville, J.W. and Haskins, F.A., 1986. Evaluation of agronomic and energy traits of Wray sweet sorghum and the N39 $\times$ Wray hybird. Energy Agric., 5: 49-54.

Recent emphasis on energy problems has stimulated efforts to identify crops capable of producing high yields of biomass that can be converted into ethanol. The sorghum [Sorghum bicolor (L.) Moench] crop includes cultivars and hybrids that vary widely in the relative amounts of grain and stalks produced, and also in the sugar content of the stalks. N39 $\times$ Wray, a relatively sweet hybrid with good grain potential, and Wray, a cultivar with sweet stalks, were compared for their grain and sugar yields, alcohol production potential, and other related characters. The hybrid produced heavier seeds, more seeds per head, and more heads per ha than the Wray. This resulted in a grain yield of $6630 \mathrm{~kg} / \mathrm{ha}$, about 3.4 times that of Wray. Wray produced about $10 \%$ more biomass with the stalk sugars accounting for about $80 \%$ of the total alcohol potential as compared to $45 \%$ for the hybrid. The total alcohol production potential (stalk plus grain) was 1.11 times as great for the hybrid as for Wray.
\end{abstract}

\section{INTRODUCTION}

The advent of possible fuel shortages has resulted in an interest in crops having the potential for producing high yields of biomass that can be converted to a more usable energy form (Lipinsky, 1978). At the same time, there has been controversy on the desirability of using biomass for energy production at the expense of feed and food crops and reduction of soil productivity with removal of crop residue (McFate, 1981; Helsel and Wedin, 1983; Kenny and Erichsen, 1983; LeBlanc, 1983). Thus, the successful use of biomass for fuels will require the careful consideration of numerous factors.

Published as Paper No. 7745, Journal Series, Nebraska Agricultural Experimental Station. Research was conducted under Projects 12-101 and 12-114. 
The ability to produce high biomass 'with high sugar content has made sweet sorghum [Sorghum bicolor (L.) Moench] attractive as a possible source of an easily transported energy form. The sorghum crop includes cultivars and hybrids that vary widely in the amount of grain and stalks produced as well as in the sugar content of the stalks. Thus, the potential exists for a dual purpose type which produces both high grain and sugar.

The objective of this research was to compare Wray sweet sorghum with the hybrid produced by crossing Wray with a short-statured sorghum A-line, N39. The traits compared were grain and sugar yields, alcohol production potential, and other related characters.

\section{MATERIALS AND METHODS}

The experimental site was located at the University of Nebraska Field Laboratory, Mead, NE. This location is characterized by a yearly average temperature of $11^{\circ} \mathrm{C}$ and precipitation of approximately $760 \mathrm{~mm}$. Highest temperatures occur during June, July and August. The highest precipitation is in May, and during the growing season, July is usually the month of lowest precipitation. Temperature and precipitation vary widely among and within growing seasons. Average temperature and precipitation for the grow. ing season (May-October) are $20^{\circ} \mathrm{C}$ and $560 \mathrm{~mm}$, respectively. The soils at this site are classified as Typic Argiudolls which are slightly acid or neutral in natural conditions.

The sweet sorghum cultivar 'Wray' (Broadhead et al., 1978), which produces a low grain yield but has stalk juice that is high in sugar content, was compared with the $\mathrm{F}_{1}$ hybrid, $\mathrm{N} 39 \times$ Wray, which is somewhat lower in juice sugars than Wray but has higher grain yield. N39 was developed from a cross of 'Combine Kafir-60' $\times$ 'Atlas' with the objective of using it as a combine-height female forage sorghum parent (Ross et al., 1980). Stalks of N39 are sweeter and juicier than those of most grain sorghums. The N39 $x$ Wray hybrid was made by split plantings of the parents. This was necessary because when the parents are planted on the same date, anthesis occurs at different times. In 1981, when N39 and Wray were planted at the same time, dates of anthesis were 12 and 26 August, respectively. Anthesis date for the hybrid was 19 August.

The experimental design was a split-plot with irrigation and no irrigation treatments as main plots and entries as subplots with four replications. The experiment was planted 29 May 1981 in a seedbed prepared by disking and harrowing the field, on which soybeans were grown in 1980 . Nitrogen was applied at a rate of $80 \mathrm{~kg} / \mathrm{ha}$ just prior to disking. Subplots consisted of six rows spaced $0.76 \mathrm{~m}$ apart and $6 \mathrm{~m}$ long with plants hand-thinned to a spacing of approximately $15 \mathrm{~cm}$. The field was treated for weed control using recommended rates of atrazine [2-chloro-4-(ethylamino)-6-(isopropylamin)$s$-triazine]/propachlor (2-chloro- $N$-isopropyl-acetanilide) as a preemergence spray. The plots were cultivated to facilitate furrow irrigation, and ap- 
proximately $2.5 \mathrm{~cm}$ of water was applied on 7 July to the irrigated treatment.

Sorghum biomass and grain yields were taken at maturity (15 October) by harvesting two 3-m rows from each plot. The harvested material was weighed for total wet biomass. The heads were removed, dried, and threshed for grain yield. Grain yields are expressed as kilograms per hectare at $14 \%$ moisture. Seed weight represents the weight in grams of 1000 seeds. Seeds per head were calculated by dividing grain weight per head by seed weight. Plant height at maturity was measured from the soil surface to the tips of the sorghum heads. Numbers of culms were estimated by counting the heads harvested from each plot.

Twenty stalks with attached leaves and heads were randomly selected from each plot. A subsample of ten was divided into stalk-sheath, leaves, and heads. Wet and dry weights were measured and the percentages applied to the total biomass for determining the component yields on an area basis. The other subsample was weighed, heads were removed, and stalks and leaves were pressed with a small roller press to extract the juice. The weight of juice was used to calculate total juice yield. Samples of juice were analyzed for total sugars, dry matter, and ash.

Potential alcohol production was estimated at 582 liters per metric tonne of sugar or starch (Scantland et al., 1979). Starch was calculated as $70 \%$ of the weight of oven-dry grain (Morrison, 1951).

Analyses of variances were performed as described by Steel and Torrie (1980).

\section{RESULTS AND DISCUSSION}

Rainfall was generally adequate during the 1981 growing season, and analyses of variance indicated that the irrigation treatment had a significant $(P \leqslant 0.05)$ effect on only two of the traits under study, yield of fresh leaves and percentage dry matter of the expressed juice. Therefore, the means shown in Tables 1 and 2 were calculated across irrigation treatments. Differences between Wray and the N39 $\times$ Wray hybrid were highly significant $(P \leqslant 0.01)$ for all traits listed in Tables 1 and 2 except yield of fresh and dry leaves.

\section{Agronomic traits}

The N39 $\times$ Wray hybrid produced heavier seeds, more seeds per head, and more heads per ha than the Wray cultivar (Table 1). These traits combined to give the hybrid a substantially higher yield of threshed grain than Wray. The yield of $6630 \mathrm{~kg} / \mathrm{ha}$ compares with the average yield of $7966 \mathrm{~kg} / \mathrm{ha}$ produced by 95 grain sorghum hyhrids grown in a replicated yield test in the same county in 1981 (Dreier et al., 1981).

Although the hybrid produced more grain than Wray, the stalk yield of 
Wray was appreciably higher than that of the hybrid. Wray produced about $10 \%$ more total biomass than the hybrid, on both a fresh weight and dry weight basis.

\section{Sugar production and alcohol potential}

As shown in Table 2, stalks of Wray yielded more juice and sugar per ha than the N39 $\times$ Wray hybrid. The juice of Wray was higher in dry matter

TABLE 1

Agronomic traits of Wray and the N39 $\times$ Wray hybrid evaluated at Mead, NE, in 1981

\begin{tabular}{|c|c|c|}
\hline \multirow[t]{2}{*}{ Trait } & \multicolumn{2}{|l|}{ Mean $^{a}$} \\
\hline & Wray & N39 $\times$ Wray \\
\hline Plant height $(\mathrm{cm})$ & 394 & 350 \\
\hline Culms (No./ha) & 88260 & 118130 \\
\hline Seeds per head (No.) & 960 & 1980 \\
\hline Seed weight (g/1000 seeds) & 22.9 & 29.2 \\
\hline Grain yield (kg/ha@14\% $\left.\mathrm{H}_{2} \mathrm{O}\right)$ & 1960 & 6630 \\
\hline \multicolumn{3}{|l|}{ Biomass yields (kg/ha) } \\
\hline \multicolumn{3}{|l|}{ Heads } \\
\hline fresh & 3020 & 10870 \\
\hline dry & 2200 & 8950 \\
\hline \multicolumn{3}{|l|}{ Leaves } \\
\hline fresh & 5420 & 4810 \\
\hline dry & 3080 & 3130 \\
\hline \multicolumn{3}{|l|}{ Stalks } \\
\hline fresh & 83160 & 67160 \\
\hline dry & 28670 & 18640 \\
\hline \multicolumn{3}{|l|}{ Total plant } \\
\hline fresh & 91600 & 82840 \\
\hline dry & 33950 & 30720 \\
\hline
\end{tabular}

a All differences between Wray and the hybrid, except those for fresh and dry weight of leaves, were highly significant $(P \leqslant 0.01)$.

\section{TABLE 2}

Yields of juice and sugar, and percentages of dry matter and ash in the juice, from stalks of Wray and the N39 $\times$ Wray hybrid

\begin{tabular}{lcc}
\hline Trait & Mean $^{\mathrm{a}}$ & \\
\cline { 2 - 3 } & Wray & N39 $\times$ Wray \\
\hline Pressed juice (kg/ha) & 49180 & 40040 \\
Dry matter (\%) & 17.7 & 14.7 \\
Ash (\%) & 4.6 & 6.6 \\
Sugar (kg/ha) & 5790 & 3740 \\
\hline
\end{tabular}

${ }^{a}$ All differences between Wray and the hybrid were highly significant $(P \leqslant 0.01)$. 
and lower in ash than that of the hybrid. However, calculation of sugar as a percentage of dry matter in the juice indicated that the two genotypes did not differ greatly (66.4\% for Wray, $63.5 \%$ for the hybrid).

Amounts of alcohol that might be produced from the sugar in the stalk and the starch in the grain of the two genotypes are shown in Table 3. The data indicate that for Wray, the stalk accounted for about $80 \%$ of the total alcohol potential; whereas for the hybrid, the corresponding value was about 45\%. Total alcohol potential (stalk plus grain) was 1.11 as great for the hybrid as for Wray.

\section{TABLE 3}

Estimated potential alcohol production from grain starch and from total sugars contained in juice pressed from stalks of Wray and the N39 $\times$ Wray hybrid

\begin{tabular}{lcc}
\hline Energy source & \multicolumn{2}{c}{ Potential alcohol production (L/ha) } \\
\cline { 2 - 3 } & Wray & N39 $\times$ Wray \\
\hline Starcha $^{\text {a }}$ & 687 & 2323 \\
Sugar $^{\mathrm{a}}$ & $\frac{3370}{4057}$ & $\frac{2177}{4500}$ \\
\hline
\end{tabular}

\section{Possible applications}

The characteristics of Wray and the N39 $\times$ Wray hybrid suggest several possible applications. In situations requiring large amounts of juice and sugar, Wray would be the obvious choice. The hybrid produced about $65 \%$ as much sugar per ha as Wray, but its production of threshed grain per ha was more than three times that of Wray. In situations where grain is needed for animal feed or human food, the hybrid may be preferred. If maximum production of alcohol were the goal, and if facilities were available to process both the juice and grain, the hybrid would again be preferred. The performance of this hybrid clearly shows that good yields of both sugar and grain can be produced simultaneously.

This study dealt with only a single sweet sorghum cultivar, Wray, and its hybrid with a single, short-statured female line, N39. No crosses of Wray with other female lines were evaluated, nor was N39 used in crosses with other cultivars of sweet sorghum. Although N39 has stalks that are somewhat sweeter and juicier than those of most grain sorghum females, no effort was made to identify or develop a female line for use in these studies that was higher than N39 in sugar content. The identification or development of such lines and their use in crosses with Wray or other seet sorghums might be expected to result in hybrids that would produce even higher yields of sugar and grain than the N39 $\times$ Wray hybrid used in these studies. 


\section{REFERENCES}

Broadhead, D.M., Freeman, K.C. and Zummo, N., 1978. 'Wray' - a new variety of sweet sorghum for sugar production. Miss. Agric. For. Exp. Stn. Res. Rep. 4, 4 pp.

Dreier, A.F., Nordquist, P.T., Elmore, R.W., Grabouski, P.H. and Nelson, L.A., 1981. Nebraska grain sorghum performance tests. E.C. 82-106, Nebraska Cooperative Extension Service, $27 \mathrm{pp}$.

Helsel, Z.R. and Wedin, W.F., 1983. Direct combustion energy from crops and crop residues produced in Iowa. Energy Agric., 1: 317-329.

Kenney, V.P. and Erichsen, R.L., 1983. Conflict between fuel and food: the ethical dimension. In: J.P. Hartnett (Editor), Midwest Universities Energy Consortium Workshops - Biomass. Incentives Workshop, 15-16 September 1981, Madison, WI. Energy Agric., 2: 285-306.

LeBlanc, M., 1983. Alcohol from grain: Global price implications. Energy Agric., 1: 347357.

Lipinsky, E.S., 1978. Fuels from biomass: integration with food and materials systems. Science, 199: 644-651.

McFate, K.L., 1981. Food and energy: challenges and choices. Energy Agric., 1: 91-98.

Morrison, F.B., 1951. Feeds and Feeding (21st Edition). Morrison, Ithaca, NY, 1207 pp.

Ross, W.M., Gorz, H.J., Haskins, F.A. and Webster, O.J., 1980. Registration of ten sorghum parental lines. Crop Sci., 20: 834 .

Scantland, D.A., McClure, T.A. and Lipinsky, E.S., 1979. Carbohydrate crops as a renewable resource for fuels production, Volume II: Identification of key policy issues, alternatives, and implications relating energy from biomass. BMI-2031, Battelle, Columbus, $\mathrm{OH}, 65 \mathrm{pp}$.

Steel, R.G.D. and Torrie, J.H., 1980. Principles and Procedures of Stastistics. A Biometrical Approach (2nd Edition). McGraw-Hill, New York. NY, 623 pp. 